\title{
モルホロジーの制御と物性 ポリマーアロイの場合
}

\section{小高忠男}

Tadao Kotaka, 大阪大学 理学部

\section{1. はじめに}

原稿締切期日が迫って，あたふたと執筆にとりかか った 12 月初旬, テレビや新聞紙上で, ニタ大学メデ ィカルセンターに和いて, 初めて“永久使用を目指し た”ポりウレタン製人工心臓の人体埋め込み手術が成 功裡に行なわれたことが報ぜられた，元来，自己修復 能力のないポリウレタン心臓などが永久に使用し続け られるはずあないので, この小論が誌上に揭載される 頓までには何らかの決着が着いているかもしれない. 高分子の生体適合性の問題にいささか関心を持つ一人 として，原稿書きもそぞろに固枆を吞んで成り行きを 見守っている.

人工心蔵開発の例をあげるまでるなく，現在ほど， 高度な性能を持った材料・新しい機能を持った材料の 開発が渴望されている時期はない，この傾向は単に高 分子材料の分野のみにとどまらず, セラミックス,電子 村料, その他あらゆる分野で見受けられる. その中で 高分子材料学は, 從来基幹となってきた石油化学や織 維工業の不振を反映してか，むしろ心もとなけ゚にさ兄 見受けられる. しかし, 高分子材料は他の材料で置換 えることのできない優れな性能を数多くもつ. 決して その前途を悲観すべきものでもないし，役割を軽視し てよいるのでもない,もちろん，いかに優れた材料で るカバーできない用途はたくさんある。例完ば，七ラ ミックスを利用した耐熱エンジンの開発は期待できて も, セラミックスタイヤなどは考兄られない. 最近, 一部の分野で見られるように「誇張された華やかそう な展望」をかかげてブームに浮かれるのではなく，高 分子物質本来の性能・機能に基礎を固いた堅実かつ独 創的な新材料の開発が追究されるべきであるう.

新規な高性能材料・高機能材料（機能性材料などと 胡散くさいことは言わないでいたださたい）の開発が 望まれる時, まず追求されることは，文字通りの新物 質の開発であうう.しかし, 現在, 高分子合成化学は 㔛まりにる成熟していろいるなことがわかっているの

Design and Control of New Morphologies and Properties for Polymer Alloys

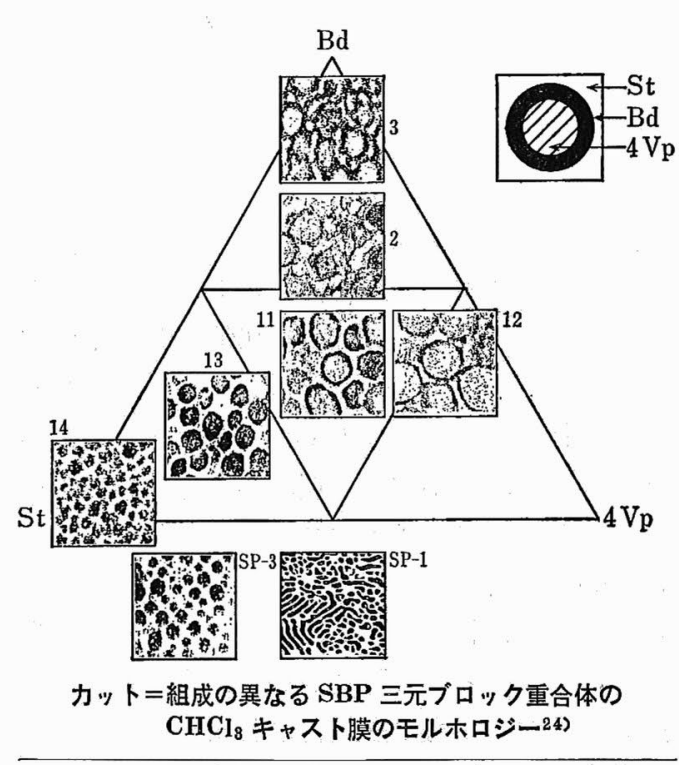

で, 希望する性能・機能を持ち, しかも, 作業上の安 全性・経済性も満足し,かつ,できれば, 環境污染や 発ガン性・遺伝毒性もないことを納得させられる新物 質はあってもなかなか思いつかないのが本音である 5. 关れが，また，既によく知られた物質について， モルホロジーを制御するなどの物理的な手段によっ て, 期待する, あるいは, 予期しない新しい性能・機 能を発揮させようといら方向の開発が指向された動機 でもあろう．高純度単結晶シリコンに対するアモルフ アスシリコンの開発はこの好例でめろう.

さて, 結晶学の分野では, モルホロジーとは “結晶 の巨視的な形態と構造”とされて和り, 高分子結晶で は, 分子鎖の折りたたみ構造・のび切り構造・ふさ状 ミセル構造などの微結晶のサイズに匹敵する程度の高 分子鎖のマクロコンホメーションによって決まるとさ

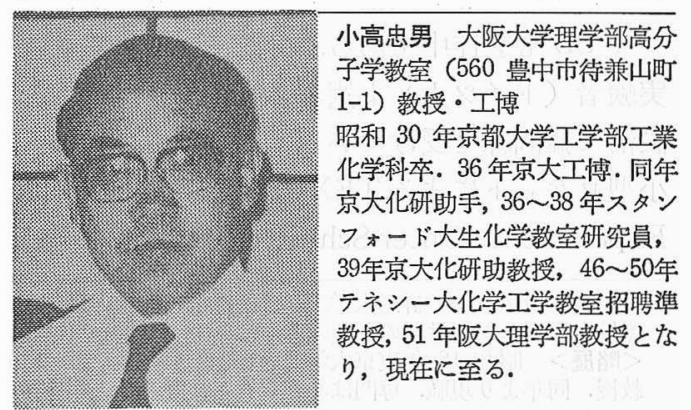
高分子 32 巻 3 月号 (1983 年) 
れている1。.この方向での展開は，例总ば， 「高結晶性高分子材料の開発」に見ることが できる.この小論では, このらち, 筆者の土 俵である無定形高分子の “ポリマーアロイ” のモルホロジーについて述べさせていただく ことにする。

\section{2. “ポリマーアロイ”とは}

それではポリマーアロイ゚゙とは何を指すの か？ その定義・内容についてはまだ般的 な合意は得られていないが，ここでは高分子 学会編 “ポリマーアロイア” の表に示された 分類に従って，高分子を 2 種類以上含んた多 成分系と定義することにする，交互共重合 体・ランダム共重合体などは成分がモノマー レベルで存在しているという意味でポリマー アロイには大れない，先の代わり, 高分子成 分が共有結合で連結されていることは必要条 件としないので, ポリマーアロイは, 異種成 分間に共有結合が存在するブロック・グラフト共重合 体グループと，共有結合の存在を前提としないポりマ ーブレンドのグループに大別される.

ポリマーブレンドには, 融解法・溶媒キャスト法な ぞの物理的方法でブレンドする物理的ブレンド, 水素 結合のような二次的な結合力によるポリマーコンプレ ックス, さらに, 異種成分・異種相間の接着性・相容 性を高めるために, 分肢反応によって生成するグラフ ト共重合体成分を乳化剂として利用する溶夜グラフト 物, 高分子の相容性には関係なしに橋かけによって2 成分から相容的な材料を得る相互貫入性高分子網目 (Interpenetrating Polymer Network: IPN) のよう な化学的ブレンドがある.この種の IPN は熱硬化的 であり, 加工性泛しいので，その欠点を補う意味で 熱可塑性の ABA 型ブロック共重合体・アイオノマー などを組合わせた熱可塑型 IPN が報告されている5). 溶液グラフト物のように偶発的泟生成するグラフト共 重合体成分を利用するのではなく, あらかじぬ分子設 計を施して合成したブロック共重合体を異種ホモポり マーの乳化剂として利用する物理的ブレンドの手法す 開発されている( $)$. これらはブロック・グラフト共重 合体の手法とポリマーブレンドの手法を組合わせたる のとして，新しい第 3 のグループに位置付けるべきか るしれない.

\section{3. モルホロジーの設計}

一般に, 異種高分子は相互に混り合わない，すなわ ち, 相溶的でないので, ポリマーアロイ中では, 大な

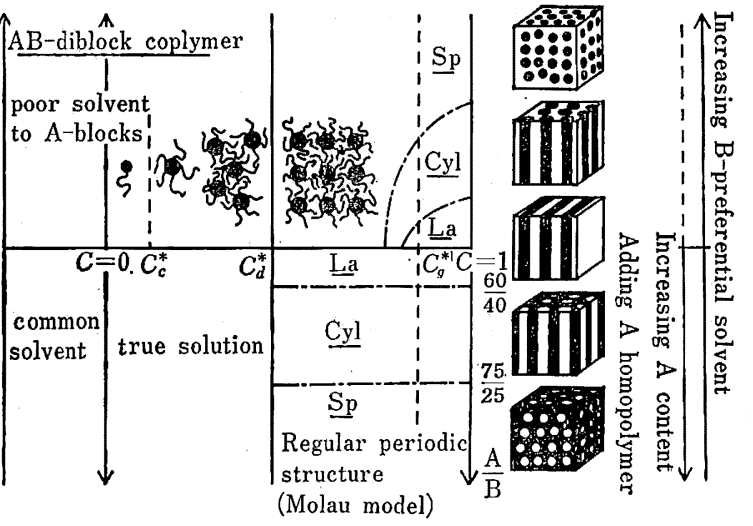

図 1 A-B 型ジプロック共重合体の溶媒キャストによるモルホロ ジ一形成過程 ${ }^{13)}$ とMolau の模型9)

選択溶媒 (A 筫溶媒) 中で法臨界ミセル濃度 $\left(C_{c}{ }^{*}\right)$ でミセル形 成が始まり，秩序化濃度 $C_{c}$ *でミセルによるマク口格子が形成さ れ, やがて固体中でポリマーの組成に応じて Molau の模型に到 達する. 共通溶媒中では均一溶液から， $C_{c}$ *でポリマー組成に 応じた規則構造の形成が始まる。ただし，いずれの場合もガラス 化濃度 $C_{g}$ *で構造が谏結される.

り小なり相分離が起こり,いわゆるミクロ相分離構造 あるいはミクロドメイン構造を形成する，したがっ て, ポリマーアロイのモルホロジーとは，旮のような 内部構造の形態と大きさを指すことにしよう。

ポリマーアロイの設計は，異種高分子成分が通常相 溶的でないことが出発点となる7). 混合熱が正の吸熱 系では，混合によるェントロピーの増加によって混合 が達成される.しかし，高分子系では低分子系に比べ て混合エントロピーが重合度の逆数のオーダー程度小 さく，一方，混合ェンタルピーは低分子系之同程度で あるので，吸熱系では注とんどの場合分子状飞混合し ない.

ブロック・グラフト共重合体で, 相分離が起こった 場合，鎖の継ぎ目がいつる相界面領域泥在化され る. そのため, 同じ重合度・組成で比べると，1本の 分子鎖中のブロック鎖（あるいは枝）の数が多いほど 相分離が起こりにくい'8). このことは同じ分子量・組 成の A-B ジブロック型共重合体とランダム共重合体 を比べたとき，後者では相分離が起こらないことから 直観的飞理解できよう.

さらK, ブロック・グラフト共重合体の特徴は, 異 種高分子鎖が共有絬合でつながっているために，相分 離は分子オーダーでしか起こり劣ず, 結果としてミク ロドメイン構造が形成されることである。このとき， 系内到る所でセグメント密度は一様でなければなら ず, かつ, 各々のミクロドメイン内ではブロック鎖は バルクのホモポリマー中と同様の（繼ぎ目が固定さ れ、異種成分のドメインから排除されることを除い 
て）コンホメーションをとる，したがって，A-B 2 成 分系を考兄た場合, ミクロドメインの形態は図 1 亿示 した Molau のモデルのように系の組成によって系統 的に変化する ${ }^{9}$ ， むた，ミクロドメインのサイズはブ ロック鎖の分子量とともに規則的に変化する年 12).な 括，この形態变化は組成変化だけでなく，たとえば， 一方の成分飞選択的に吸収される溶媒を添加する場合 飞も，あるいは，一方のホモポリマーを溶かし込む場 合にも見られる年). 選択的溶媒・ホモポリマーの增加 は，その成分の体積分率の增加と同等の効果をるたら す.ただし，モルホロジーの規則性はこれらの添加に よって一般飞減少する ${ }^{12}$.

な特，成分の一方，または，両方が結晶性の場合， ポリマーブレンドでも, ブロック・グラフト共重合体 でも, 相分離に結晶化の自由エネルギーの寄与が加わ り, 結晶の融点以下では, 固・液型相分離が現われ, 融点以上では液・液型相分離が現われる ${ }^{8)}$. 前者の場 合, ミクロドメイン形成に执いても，結晶化江有利な モルホロジーが支配的となる12).

ポリマーアロイの相分離構造形成の祭, とくに成分 高分子のガラス転移温度以下では, 一つの平衝状態か ら他の平衡状態汇高分子鎖が移行する速さがきわめて 遅い，すなわち，緩和時間が極めて長い，このことが モルホロジー設計を困難にするとともに，逆に，余分 の自由度を与兄る要因となる，たと党ば，図1飞示す ように,ブロック共重合体を溶媒キャスト法によって 製膜するとき，濃縮過程で形成されたミクロドメイン 構造がある濃度 $C_{g}$ * で涷結されて，溶媒が完全に除 去された後も, 熱力学的には最安定構造でないにもか かわらずそのモルホロジーが保持される。

こうして，組成とブロック鎖の長さだけでなく，成 膜条件を制御することによるモルホロジーの設計が可 能となる。たと党ば，スチレン含量 $30 \%$ 程度の同一 のスチレン・ブタジェンースチレン (SBS) ブロック共 重合体を $\mathrm{S}$ 相潠択的に分配されるテトラヒドロフ ラン/メチルエチルケトン溶媒からキャストすると, $\mathrm{S}$ 成分の多いとき見られるラメラ構造が現われるのに 対して， B 相倊配されるシクロへキサン/ベンゼン (C/B) 溶媒からキャストすると， $\mathrm{S}$ 球状/B マトリッ クス構造に近いモルホロジーが現われる.この準安定 構造は結構安定で, 膜を伸長・収縮していったん破壊 しても、アニールによってそれぞれもとの準安定構造 を回復する. そこで, 膜の力学的性質ももとの構造に 対応した状態に回復する ${ }^{14)}$.

ポリマーブレンドの場合には, 成分高分子が相溶的 でなければ，調製の方法によって，完全混合状態か ら，マクロに相分離した状態まで, 中間のいずれの状

態も実現しらることになり，モルホロジーの制御は難 し(15),16). そこで，化学的ブレンドの手法や，ブロ ック共重合体を乳化剤とした制御(6)，17)，18) が試みられ ることになる，話は前後するが，ホモポリマーをブロ ック共重合体（グラフト共重合体でも）にブレンドす る場合，その分子量がブロック鎖の分子量よりも小さ いと，ホモポリマーはブロック鎖のミクロドメインに 可溶化し，その成分の多いブロック共重合体と同じモ ルホロジーを示す，逆に，大きい場合には，別個のド メインを形成する ${ }^{17), 18)}$ ，その場合，マトリックスを形 成しているミクロドメイン構造が力学的性質を支配す $b^{14)}$.

IPN の場合には，成分間の相溶性にかかわりなく， 橋かけ反応によって強制的飞混合させ，任意の木モポ リマーの組合わせをアロイ化することができる19)，と の反面，ミクロドメインの形態・サイズは，いわば， 成行き次第でモルホロジーの設計は難しい，両成分の 相溶性よりも，むしろ，橋か村密度を調節することに よってある程度の制御が可能である。

\section{3 成分系アロイ}

ゴム成分を分散させた耐衝撃プラスチックで， 3 成 分系によってモルホロジーの制御をより精密に行な い,かつ，新しいモルホロジーを造り出す試みがあ る6)。その一つは，分子量の異なる 2 種類の A-B 型 ブロック共重合体を，プラスチック成分である $\mathrm{A}$ 木 モポリマーにブレンドするもので，2種のブロック共 重合体成分による “タマネギ構造”をるつ球形ミク口 ドメインを $\mathrm{A}$ ポリマー中に分散させることができる. ゴム成分 $\mathrm{B}$ を含んだ, ある程度のサイズのタマネギ 状ミクロドメインによって耐衝撃性を確保するととも に，A-B を薄皮のタマネギ状にすることによって透: 明性を持たせようとする試みである6).

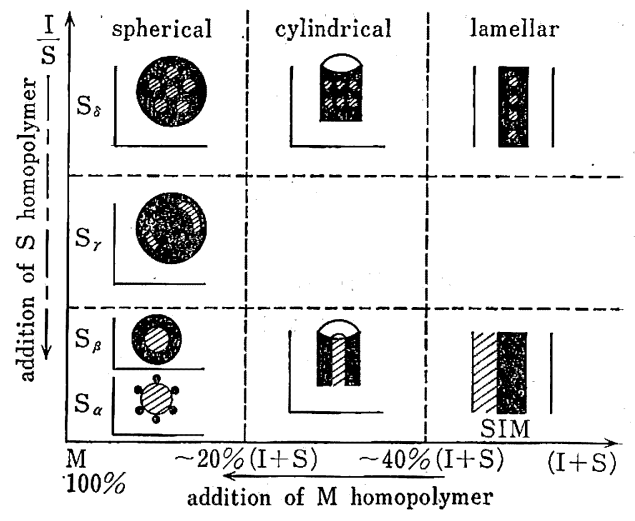

図 2 RiessによるSIM/S/M ブレンド系のモルホロ

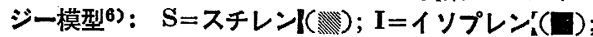
$\mathrm{M}=$ メタクリル酸メチル (口) 
さらに興味深い試みは $\mathrm{ABC}$ 三元重合体を乳化剤に

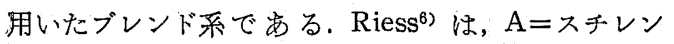
(S)，B=イソプレン(I)，C=メタクリル酸メチル （M）を用いた SIM 三元ブロック重合体と，S 抒上 び M ホモポりマーのブレンド系のモルホロジーを,

2 成分系に和ける Molau の規則》基づいて制御す ることを試みている，この 3 成分系アロイのモルホ ロジーは, $M$ の体積分率 $\phi_{M}=M /(I+S+M)$ と, $(I+S)$ 相中の $I$ と $S$ の体積比 $r_{I / S}=I / S$ Kよって 規定される.すなわち，図2 に模式的に示すように， $\phi_{M}$ によって $M$ 相対 $(I+S)$ 相の関係が定まる. $\phi_{M}$ を上げるにしたがって， $M$ 相/ $(I+S)$ 相交互ラメラ 状から, $(I+S)$ 相が円柱状, 球状へと変化する. 一 方， $\phi_{M}$ を一定保ったなま，rI/S を大きくすると， それぞれのドメイン内で, $I$-分散相 $/ S$-マトリックス 型から，I/S 交互ラメラ型, $I$-マトリックス/S-分散 相型へと移り変わることが指摘されている.

同様な三元系アロイのモルホロジーに対する Molau の規則の適用は, 組成を変えた S-I-p-ジメチルアミ ノスチレン（A）三元ブロック重合体についてる成立 つことが藤本ら ${ }^{203}$ そって見いだされている。しか し，この系をさらに拡張した B-S-B-A-B 三元 5 ブ ロック重合体（ただし B=ブタジェン）ではいつも交 互ラメラ構造が見られることが報告されている21).

筆者らは, SB ブロック共重合体に相容性の悪い 4-ビニルピリジン $(\mathrm{P})$ 鎖とつないた SBP 三元ブロ ック共重合体のモルホロジーと力学的性質の関係を詳 しく調べた22) 25). 3 成分の組成が活淩 $1: 1: 1$ のも のを用いると, $\mathrm{CHCl}_{3}$ のような $\mathrm{SB}$ 相の良溶煤で $\mathrm{P}$ 相の貧溶媒からキャストすると, 中心の $\mathrm{P}$ 球状ドメ

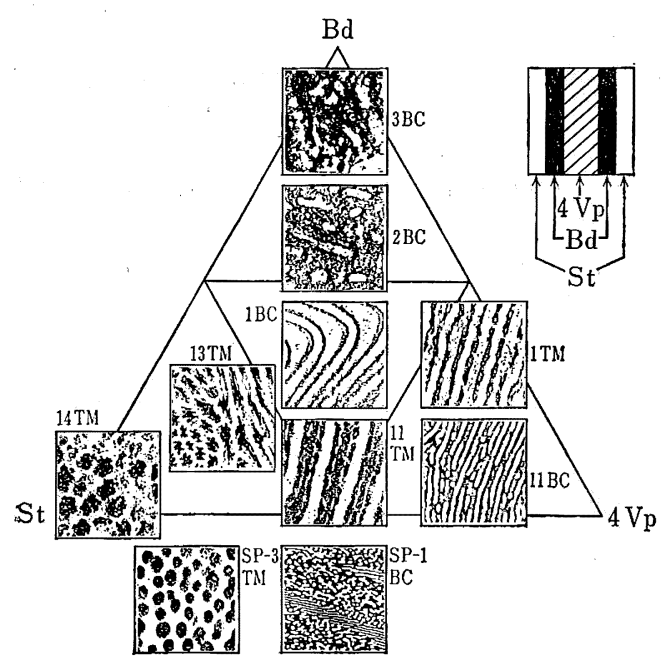

図 3 組成の異なる SBP 三元ブロック重合体の BA 系 および THF/MeOH 混合溶媒系からのキャスト膜の モルホロジー24)
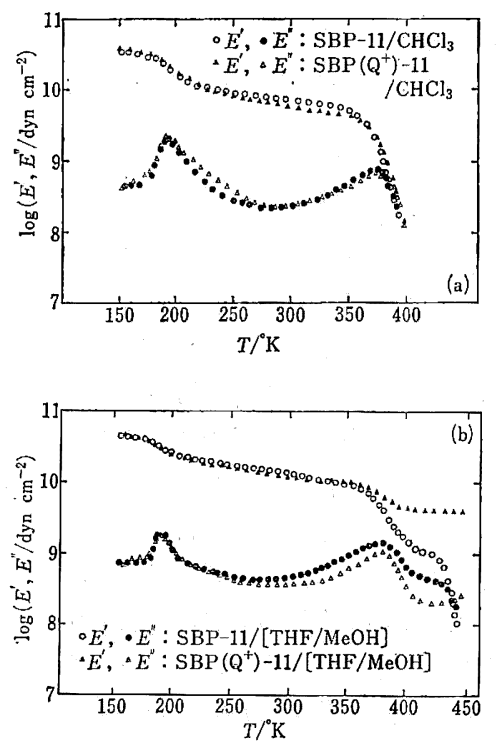

図 4 SBP-11 の (a) $\mathrm{CHCl}_{8}$ および (b) THF $/ \mathrm{MeOH}$ キャスト膜とそれらのその四級化試料 $\operatorname{SBP}\left(Q^{+}\right)-11 の$ 複素弾性率と温度の関係 24

インを B 相が包み、さらにそれが S 相の箱に収った “箱球構造”を呈する 22 (“チャイナマーブル構造”之 呼ぶ方がよいとの意見も㐫る)、また,ブチルアルデヒ ド $(\mathrm{BA})$ のような $\mathrm{P}$ 相の良溶媒からキャストすると, SBP の 3 相が交互に現われる “ 3 層ラメラ構造”を呈

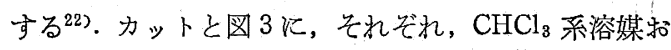
よび BA 系溶媒からキャストした種々の組成の SBP 三元ブロック重合体膜のモルホロジーを示す透過電顕 写真を, 組成を表わす三角ダイヤグラム上に配列して 示した ${ }^{24)}$. このように SBP 三元ブロック重合体で る, 分子量・組成の他飞製膜法の調節によってモルホ ロジーが制御できる。

これらのモルホロジーの異なる膜の力学的性質を調 ベると，興味ある事実が見いだされる：すなわち，複 素弾性率の温度依存性を見ると, 箱球構造膜では, 図 $4(\mathrm{a})^{24)}$ のように，B相とS 相の緩和はとれぞれの小 モポリマーのガラス転移温度付近飞観測されるが, ガ ラス転移温度の一番高いP相の緩和は観測されない222.

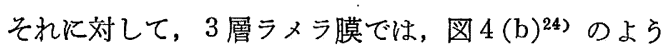
飞, 3 成分の緩和がいずれもとれぞれのガラス転移温 度で観測できる ${ }^{22)}$.さらに, これらの膜を $\mathrm{CH}_{8} \mathrm{Br}$ に よって気相中で 4-ビニルピリジンの四級化を行なう と,モルホロジーには変化が見られない233,24). 同時 に, 複素弾性率と温度の関係です, 図 4 でわかるよう 飞, P 相が緩和に寄与しない箱球構造膜では四級化の 影響が見られないのに対し，3層ラメラ膜では四級化 によって P 相のガラス転䔟温度が著しく高くなって いる ${ }^{23), 24)}$.このような SBP 三元ブロック重合体膜 
のモルホロジーと力学的性質の関係は, 有限要素法を 用いた解析によって説明できる25),26).

\section{5. おわりに}

ポリマーアロイのミクロドメイン構造は, 熱力学的 に安定な構造であれ, 強制的に造り出された準安定構 造であれ，材料の最終的な性能・機能に大きな影響を 及汸す。うして, ポリマーアロイに特ける分子設計 とモルホロジー制御による物理的性質の設計が可能と なる、な特，この小論ではバルクのモルホロジーと物 性についてのみふれたが, はじめに述べた人工心蔵の ような抗血栓性の要求される材料では, 表面・界面構 造の設計もまた極めて重要な課題である.これらのす ベての課題について今後の発展が町望される.

この小論を脱稿する時点では, バーニイ・クラーク 氏の人工心藏は一部修理したるのの，まだ機能してい るようである，この大胆な試みが同氏にとっても，ま た，試験者の側にとってま rewarding なりのである ことを祈る次第である.

この小論に引用した筆者らの研究は, 文部省科学研 究助成金（147087 および 543026）の援助による.こ の援助に対し心から感謝する。

\section{文献}

1) B. Wunderlich: Macromolecular Physics, Academic Press (1973) vol. I, pp 178 180

2) M. Shen, H. Kawai: AICHE. J., 24, 1 (1978)

3）高分子学会編：ポリマーアロイ一基礎と応用, 東 京化学同人 (1980) pp 1 6

4) M. Shen, T. Kotaka, eds. : Proc. US-Japan Joint Seminar on Multicomponent Polymers, Kyoto, 1978 (J. Macromol. Sci.-Phys., B17, Nos. 2 4), Marcel Dekker (1980)

5) D. L. Siegfried, D. A. Thomas, L. H. Sperling: J. Appl. Polym. Sci., 26, 177 (1981); Polym. Eng. Sci., 21, 39 (1981)

6) G. Riess, M. Schlienger, S. Marti : J. Macromol. Sci.-Phys., B17, 355 (1980); 文献 4)

7) 小高忠男 : ブラスチックス, 32, 10 (1981)

8) S. Krause: Macromolecules, 3, 84 (1970); J.
Macromol. Sci., C7, 251 (1972)

9) G. E. Molau : Block Polymers(S. L. Aggarwal, ed.), Plenum Press (1970)

10) D. J. Meier: Polym. Prepr., 15, 171 (1974); Blood and Graft Copolymers (J. J. Burke, V. Weiss, eds.), Syracuse Univ. Press (1973)

11) E. Helfand, Z.R. Wasserman: Macromolecules, 11, 960 (1978); ibid., 13, 994 (1980)

12）橋本竹治：グラフト敊よびブロック共重合体の統 計熱力学, 文献 3) 第 4.1 章

13) C. Sadron, B. Gallot: Makromol. Chem., 164, 301 (1973)

14) T. Kotaka, T. Miki, K. Arai: J. Macromol. Sci. - Phys., B17, 303 (1980), 文献 4)

15) 後藤邦夫：ポリマーブレンドの調製，文献 3) 第 $1 \cdot 1$ 章

16) 高柳素夫 : ポリマーブレンドの高次構造と物性, 文献 3) 第 $3 \cdot 3$ 章

17) $T$. Inoue, T. Soen, T. Hashimoto, $H$. Kawai: Macromolecules, 3, 87 (1970)

18）河合弘妯：ブロック共重合体のミクロ相構造とカ 学的性質, 文献 3) 第 4.2 章

19）柴山恭一, 鈴木康弘：IPN の応用, 文献 3）第 5.5 章

20) Y. Matsushita, H. Choshi, T. Fujimoto, M. Nagasawa: Macromolecules, 13, 1053 (1980)

21）瀬 和則, 宮木義行, 五十野善信, 藤本輝雄 : 高 分子学会予稿集, 31，2641 (1982); 宮本康司, 船橋英雄, 五十野善信: 高分子学会予稿集, 30, 2114 (1981); 谷杉英昭, 五十野善信, 藤本輝雄 : 高分子学会予稿集, 30, 2118 (1981)

22) K. Arai, T. Kotaka, Y. Kitano, K. Yoshimura: Macromolecules, 13, 455 (1980); ibid., 13, 1670 (1980)

23）K. Arai, T. Kotaka：投稿準備中；荒井宏一, 植田千鶴, 小高忠男, 北野幸重, 吉村堅次：高分 子学会予稿集, 29, 436 (1980); 荒井宏一, 小高 忠男, 吉村堅次, 村山和永：高分子学会予稿集, 29, 1911 (1980)

24）久戸瀬極, 荒井宏一, 小高忠男, 吉村堅次, 村山 和永：高分子学会予稿集, 31，2573 (1982); I. Kudose, T. Kotaka：投稿準備中

25) H. Watanabe, T. Kotaka: Polym. J., 13, 149 (1981)

26）小高忠男：モルホロジーと物理的性質，文献 3) 第 $2 \cdot 3$ 章 